\title{
Social Capital in Supporting Indonesian Female Workers Affected by COVID-19
}

\author{
Ernalem Bangun ${ }^{1}$, Anindita Nur Hidayah ${ }^{2}$, Maria Emeninta ${ }^{3}$ \\ \{ernabangun@yahoo.com ${ }^{1}$, anindita.nh@gmail.com ${ }^{2}$, maria.emeninta@gmail.com ${ }^{3}$ \} \\ Fakultas Keamanan Nasional, Universitas Pertahanan Indonesia, Bogor, Indonesia ${ }^{12}$ \\ Komite Kesetaraan Konfederasi Serikat Buruh Seluruh Indonesia, Jakarta, Indonesia ${ }^{3}$
}

\begin{abstract}
COVID-19 pandemic significantly affected female workers. Their rights that have been marginalized have been increasingly degraded during the implementation of social restrictions. It became a double impact, socially or economically, because female workers as a housewife were forced to bear the burden of their family, and at the same time they had to be a mother to teach their children because of the school-from-home programme. Some of them experienced a more severe impact than others because their husband lost his job so that the wife took over the burden of the whole family. However, these female workers had social capital that was able to help them economically and psychologically in continuing their activities during pandemic. Using qualitative method and social capital theory, we found that the existence of social gatherings can support their economy. Even simply doing sharing with their peers has a direct impact on these female workers' mental health.
\end{abstract}

Keywords: female workers, COVID-19, pandemic impact, social capital.

\section{Modal Sosial dalam Membantu Para Pekerja Perempuan Indonesia Terdampak COVID-19}

\begin{abstract}
Abstrak. Pandemi COVID-19 memberikan dampak yang signifikan bagi para pekerja perempuan. Hak-hak mereka yang terpinggirkan semakin terdegradasi selama pemberlakuan pembatasan sosial. Hal ini kemudian berefek ganda, secara sosial maupun ekonomi, karena pekerja perempuan sebagai ibu rumah tangga terpaksa menanggung beban keluarga, sekaligus harus menjadi ibu untuk mendidik anaknya karena adanya program sekolah dari rumah. Beberapa di antaranya mengalami dampak yang lebih parah yang disebabkan oleh suami yang kehilangan pekerjaan, sehingga istri mengambil alih beban seluruh keluarga. Namun para pekerja perempuan ini memiliki modal sosial yang mampu membantu mereka secara ekonomi dan psikologis dalam melanjutkan aktivitasnya di tengah pandemi. Dengan menggunakan metode kualitatif dan teori modal sosial, kami menemukan bahwa keberadaan perkumpulan sosial dapat mendukung perekonomian mereka. Bahkan sekadar berbagi dengan sejawatnya kemudian dapat berdampak langsung pada kesehatan mental para pekerja perempuan ini.
\end{abstract}

Kata kunci: pekerja perempuan, COVID-19, dampak pandemi, modal sosial. 


\section{Pendahuluan}

COVID-19 menyebar ke negara-negara di dunia sejak awal tahun 2020 dan teridentifikasi muncul di Indonesia pada 2 Maret 2020, hingga kemudian ditetapkan sebagai pandemi pada 12 Maret 2020 oleh WHO (World Health Organization)[1]. Penyebaran virus yang begitu cepat di Indonesia membuat pemerintah menjadikannya sebagai bencana nasional pada 14 Maret 2020. Indonesia sempat menempati urutan tertinggi ke-23 dunia pada 9 Juli 2020 dengan total 70.736 kasus positif COVID-19 (34.668 kasus aktif dan 3.417 kasus meninggal) [2].

Merespons masifnya penyebaran virus ini, pemerintah mengeluarkan kebijakan guna memutus rantai penularan dengan membatasi mobilisasi dan interaksi antarmanusia, baik di dalam negeri maupun dari/ke luar negeri. Selain itu, pemerintah juga menetapkan lima protokol utama berkaitan dengan COVID-19, yaitu Protokol Kesehatan, Komunikasi, Pengawasan Perbatasan, Area Institusi Pendidikan, serta Area Publik dan Transportasi [3]. Pemerintah juga menetapkan kebijakan lain berupa Keputusan Presiden Nomor 7 Tahun 2020 tentang Gugus Tugas Percepatan Penanganan COVID-19. Gugus tugas tersebut diketuai oleh Kepala Badan Nasional Penanggulangan Bencana (BNPB). Selain kebijakan-kebijakan tersebut, pemerintah memberlakukan kebijakan Pembatasan Sosial Berskala Besar (PSBB) di beberapa daerah yang mengalami kenaikan drastis jumlah kasus positif COVID-19. Namun demikian, kebijakan PSBB tersebut juga memberikan dampak besar terhadap kehidupan masyarakat di segala sektor, terutama sektor ekonomi dan sosial. Akibat besarnya dampak dari penerapan kebijakan tersebut di sektor ekonomi, beberapa perusahaan terpaksa mengambil langkah untuk melakukan Pemutusan Hubungan Kerja (PHK) terhadap sebagian karyawan mereka.

Terkait kebijakan yang diambil perusahaan berkenaan dengan para pekerja yang dirumahkan ataupun di-PHK, perempuan memiliki kekhususan yang menjadikannya menarik untuk dicermati lebih dalam. Walaupun hingga saat ini Indonesia telah mengupayakan terciptanya kesetaraan gender, namun ternyata isu-isu sensitif gender masih tetap perlu diperhatikan dan dikaji lebih mendalam. Terlebih pada masa pandemi COVID-19, kalangan masyarakat yang sangat terdampak, termasuk oleh implementasi PSBB maupun maraknya PHK, salah satunya adalah para perempuan, terutama para ibu, dengan peran-peran yang harus mereka jalankan sebagaimana konstruksi sosial yang telah melekati mereka, baik di sektor publik (aktivitas luar rumah, seperti bekerja) maupun domestik (aktivitas dalam rumah, seperti mengurus anak).

Berangkat dari kondisi di atas, kami melakukan penelitian untuk mendapatkan informasi dan fakta akurat tentang situasi buruh/pekerja perempuan dalam menghadapi pandemi COVID-19. Situasi yang dimaksud terutama muncul akibat pemberlakuan kebijakan penanganan COVID-19 oleh perusahaan tempat mereka bekerja. Dalam hal ini, yang menjadi fokus dari penelitian ini adalah bagaimana modal sosial dapat membantu para pekerja perempuan menghadapi situasi sulit pandemi COVID-19. Penelitian dilakukan hanya di sektor formal mengingat situasi pandemi COVID-19 telah mengakibatkan kesulitan dalam mencari data lapangan secara langsung.

Istilah modal sosial (social capital) pertama kali muncul pada 1916 untuk mendiskusikan bagaimana tetangga dapat bekerja bersama. Modal sosial diasosiasikan dengan aset-aset terlihat yang berperan dalam kehidupan sehari-hari kebanyakan masyarakat. Modal sosial kemudian juga dapat didefinisikan sebagai hubungan, nilai, serta pemahaman bersama dalam kehidupan masyarakat yang memungkinkan setiap individu ataupun kelompok percaya satu sama lain dan bekerja bersama-sama [4]. Adapun menurut definisi yang ditawarkan oleh 
OECD, modal sosial dapat dipahamkan sebagai jejaring bersama yang berdasar pada norma, nilai, dan pemahaman bersama yang dapat memberikan fasilitas kerja sama di dalam atau di antara kelompok. Dalam definisi ini, dapat pula dipahami bahwa modal sosial adalah jaringan yang berfungsi sebagai hubungan dunia nyata antarkelompok atau individu. Dengan demikian, dapat dipahami bahwa modal sosial mengacu pada sumber daya yang tersedia bagi orangorang/individu maupun sebuah entitas karena adanya jejaring yang terjadi di antara mereka.

Modal sosial sendiri memiliki beberapa varietas, antara lain "ikatan" (bonds), "jembatan" (bridges), dan "kaitan" (linkages). Ikatan berarti tautan rakyat berdasarkan rasa kesamaan identitas ("people like us"), seperti keluarga, teman dekat, dan orang yang memiliki budaya atau etnis yang sama [4]. Jembatan berarti tautan yang melampaui rasa identitas bersama, misalnya tautan dengan teman, kolega, dan rekan yang jauh. Adapun kaitan merupakan hal yang menghubungkan orang atau kelompok yang berada pada strata sosial yang berbeda yang biasanya berdasar pada kondisi ekonomi.

Konsep modal sosial pada dasarnya merujuk pada kapasitas untuk memperoleh barang material ataupun simbolik yang bernilai keanggotaan bagi seorang individu dalam kelompok sosial untuk dapat menikmati keuntungan dari tindakan kolektif berdasarkan partisipasi sosial, kepercayaan terhadap institusi, atau komitmen untuk menetapkan cara dalam melakukan sesuatu [5]. Dengan modal sosial, teman ataupun keluarga dapat saling membantu dalam banyak hal, baik secara emosional, sosial, maupun ekonomi.

Konsep modal sosial saat ini banyak digunakan oleh para akademisi maupun praktisi dalam berbagai kajian, hadir sebagai alternatif bentuk modalitas lain seperti modal ekonomi, modal budaya, dan modal manusia. Teori mengenai modal sosial sendiri lahir karena selama 50 tahun terakhir, kebanyakan pengarusutamaan ilmu ekonomi menjadi sangat formalistik, melekat pada metode dan teknik yang semakin sempit dengan mengorbankan pendekatan lain. Hal ini menjadikan teori ekonomi neoklasik memperluas domain aplikasinya ke ilmu sosial lain, namun tetap saja tidak mampu menangani fenomena sosial dan perkembangan terkini ekonomi dunia [6]. Dengan terjadinya krisis keuangan dunia serta kemunduran neoliberalisme dan postmodernisme, prospek ekonomi politik kemudian menguat. Hal ini memungkinkan hubungan yang konstruktif antara ilmu sosial dan kemunculan teori-teori kapitalistik. Oleh karena itu, teori modal sosial kemudian terbentuk dengan tujuan untuk mendukung kebangkitan dan pembaruan ekonomi politik, baik dalam dirinya sendiri maupun dalam dialog dengan ilmu-ilmu sosial lain untuk menilai secara kritis pengarusutamaan ekonomi, membahas perkembangan kontemporer, serta menawarkan alternatif-alternatif kebijakan.

Terdapat setidaknya delapan instrumen pembentuk modal sosial. Instrumen-instrumen tersebut saling melengkapi, sehingga dapat menciptakan sebuah modal sosial yang kuat. Kedelapan unsur pembentuk Modal Sosial tersebut tidak harus berurutan, namun menjadi satu kesatuan, antara lain adanya keberagaman (diversity), rasa saling memiliki (sense of belonging), penghubung antar-jejaring (networks bonding bridging), perasaan saling percaya dan aman (feeling of trust and safety), adanya timbal balik (reciprocity), partisipasi terutama dari individu-individu dalam kelompok yang sama (participation), kekuatan masyarakat terutama untuk bersatu dan saling membantu (citizen power), serta adanya kesamaan nilai, norma, dan pandangan hidup (values, norms, outlook in life) [7]. Unsur-unsur tersebut sangat penting dimiliki oleh suatu entitas untuk kemudian dapat menciptakan modal sosial. Oleh karena itu, dapat dipahami bahwa modal sosial secara teoretis dapat terbentuk jika setidaknya sebagian dari kedelapan instrumen tersebut terpenuhi. 


\section{Metode}

Untuk mendapatkan data dalam melakukan penelitian tentang modal sosial yang membantu para pekerja perempuan dalam menghadapi dampak COVID-19, kami menggunakan metode penelitian kualitatif. Penelitian dilakukan selama tiga, yakni bulan Agustus hingga Oktober 2020. Pengambilan data dilakukan dengan menggunakan kuesioner berisi pertanyaan-pertanyaan terbuka dan tertutup yang disebar kepada para responden melalui layanan Google Form. Hal ini dilakukan karena keterbatasan untuk melakukan kontak dengan para informan, mengingat situasi pandemi COVID-19 yang masih berlangsung selama periode penelitian. Di samping itu, kami juga melakukan wawancara semi-terstruktur melalui video call dengan para informan untuk melakukan pendalaman, yang sebagian di antaranya diperdalam dengan wawancara langsung, terutama bagi mereka yang sulit untuk mengakses teknologi dan memahami poin-poin survei secara jelas.

Penelitian ini dilakukan kepada para pekerja formal di 15 provinsi di Indonesia. Untuk itu, responden survei diambil dari mayoritas anggota KSBSI (Konfederasi Serikat Buruh Seluruh Indonesia) berdasarkan tingkat keaktifan pergerakan Komisi Kesetaraan KSBSI, terutama di tingkat provinsi. Pertimbangan ini terkait dengan kepatuhan pengguna pekerja pada aturan pemerintah dan tidak sewenang-wenang dalam menetapkan keputusan terkait pekerjanya, baik laki-laki maupun perempuan. Perolehan akhir total responden adalah 674 orang perempuan yang terdiri atas 582 anggota KSBSI dan 92 non-anggota/partisan.

\section{Hasil dan Pembahasan}

Hasil survei yang telah dilakukan menunjukkan bahwa pandemi COVID-19 memberikan pengaruh yang besar terhadap para responden penelitian yang merupakan para pekerja perempuan. Dampak tersebut tidak hanya terjadi pada kehidupan sosial mereka karena harus melakukan pembatasan sosial, namun juga pada kehidupan ekonomi mereka. Berbagai dampak bagi kehidupan sosial dan ekonomi para pekerja perempuan ini tidak hanya diakibatkan oleh pandemi itu sendiri, melainkan juga oleh kebijakan-kebijakan yang dikeluarkan pemerintah terkait penanganannya yang berpengaruh terhadap aktivitas perusahaan tempat mereka bekerja. Keadaan pekerja tersebut dapat dikategorikan sebagai berikut:

Tabel 1. Keadaan Pekerja di Indonesia Pada Masa Pandemi COVID-19.

\begin{tabular}{clcc}
\hline No & \multicolumn{1}{c}{ Status Responden } & Jumlah & Persentase (\%) \\
\hline 1 & Tetap bekerja dengan upah penuh & 195 & 26.7 \\
2 & Tetap bekerja dengan upah tidak penuh & 117 & 17.4 \\
3 & Dirumahkan dengan upah tidak penuh & 180 & 26.7 \\
4 & Dirumahkan dengan upah penuh & 16 & 2.4 \\
5 & PHK tanpa pesangon & 75 & 11.1 \\
6 & PHK dengan pesangon & 26 & 3.9 \\
7 & Bekerja dari rumah dengan upah penuh & 33 & 4.9 \\
8 & Bekerja dari rumah dengan upah tdk penuh & 16 & 2.4 \\
\hline
\end{tabular}

Tampak dari tabel di atas bahwa para pekerja perempuan mengalami dampak atas kebijakan pemerintah untuk menangani COVID-19. Para pekerja perempuan yang pada umumnya sudah 
berumah tangga (90\%), memiliki tugas ganda. Selain sebagai pekerja dengan berbagai tugas dan tanggung jawabnya, mereka juga harus menyiapkan segala keperluan rumah tangganya, termasuk menyiapkan segala keperluan sekolah anak-anaknya. Namun dengan situasi pandemi COVID-19 dan adanya aturan mengenai pembatasan ruang gerak, maka anak-anak pun belajar dari rumah. Bagi anak-anak yang belajar di tingkat SD, orang tua kemudian juga menjadi pendamping bagi anak-anak dalam melaksanakan berbagai tugas yang diberikan oleh guru. Selain itu, masing-masing keluarga juga perlu biaya tambahan untuk membeli masker dan hand sanitizer pada masa pandemi COVID-19 ini. Peran ibu sangat tinggi dalam melakukan internalisasi nilai-nilai untuk mengikuti protokol kesehatan, seperti memakai masker, mencuci tangan, menjaga kekebalan tubuh, serta menjaga jarak. Sebanyak $76 \%$ responden telah melakukan kegiatan ini.

Menjamin ketersediaan masker siap pakai, hand sanitizer, dan vitamin di rumah juga membutuhkan biaya. Bagi pekerja perempuan yang tetap bekerja dan mendapat upah penuh, tambahan pengeluaran untuk memenuhi kebutuhan akan paket internet, panganan untuk anakanak belajar, memberi tips bagi tetangga yang membantu anaknya belajar di rumah, dan membeli alat perlindungan diri bukanlah sesuatu yang sangat mengganggu. Berbeda halnya dengan pekerja perempuan yang tetap bekerja namun tidak dibayar penuh; keadaan ini membuat mereka kewalahan sehingga harus melakukan berbagai manuver untuk dapat mempertahankan keadaan ekonomi rumah tangga. Semua itu memaksa pekerja perempuan untuk memutar otak demi bisa bertahan hidup.

Namun demikian, para pekerja perempuan yang memang sudah selalu bergelut menghadapi masalah perekonomian rumah tangga, ternyata memiliki kemampuan untuk mengatasi permasalahan akibat pandemi COVID-19. Para pekerja perempuan yang berada di rumah, khususnya yang tidak lagi berpenghasilan (tidak dibayar perusahaan), melakukan usaha mandiri di sektor informal seperti menjahit. Terdapat pula pekerja perempuan yang menjadi penjahit masker dan menjualnya sendiri, membuka usaha katering, membuka kursus daring, menjual bunga, dll. Namun, kami jumpai pula pekerja perempuan yang bermukim di Banten yang kemudian memutuskan kembali ke kampung halamannya di Jawa Timur untuk bertani di lahan warisan orang tuanya. Banten dianggap tidak cocok bagi keluarga ini. Suami yang sebelumnya bekerja di hotel terkena PHK dan mendapatkan pesangon walau tidak sesuai aturan. Pesangon tersebut kemudian dijadikan modal untuk bertani di Jombang, Jawa Timur.

Selanjutnya, kami akan mendiskusikan bagaimana modal sosial membantu para pekerja perempuan mengatasi situasi hidup di masa pandemi COVID-19. Modal sosial tidak terlepas dari keanggotaan dalam jejaring sosial yang di dalamnya ada aturan-aturan dan rasa saling percaya yang dimanfaatkan untuk menyelesaikan persoalan-persoalan bersama. Terdapat beberapa bentuk (tipologi) modal sosial dalam sektor informal yang umumnya memberikan manfaat besar bagi para pekerja perempuan pada masa pandemi COVID-19, antara lain organisasi kedaerahan, jaringan kekerabatan/keluarga, organisasi sentimen masa lalu, jejaring pertemanan, dll.

Berdasarkan hasil penelitian, organisasi kedaerahan merupakan salah satu bentuk modal sosial yang berperan riil dalam membantu para pekerja perempuan karena terbukti dapat memberikan tambahan pendapatan bagi keluarga pekerja perempuan, khususnya yang mengalami hambatan ekonomi pada masa pandemi. Dalam tipologi ini, terdapat unsur popularitas bagi pihak yang memberikan bantuan yang berasal dari daerah/asal yang sama. Nama dari pihak yang membantu akan populer di kampungnya, sehingga menimbulkan prestise tersendiri. Dengan demikian, kebanyakan orang saling memberikan bantuan kepada seseorang yang berasal dari daerah yang sama karena terjadi penyebaran informasi. Menjadi 
hal yang semakin positif ketika info ini kemudian semakin menyebar hingga membentuk jejaring modal sosial.

Terdapat pula jejaring modal sosial yang secara khusus dimiliki oleh para perempuan saja. Ada yang menamainya Arisan, Serikat Tolong Menolong, Paguyuban, Persadan Anak Kuta, dll. Perkumpulan ini pada awalnya didasarkan pada hubungan emosional karena kesamaan sejarah, asal daerah, asal sekolah, ataupun pertalian kekerabatan. Perkumpulan ini biasanya dibentuk dari kesepakatan beberapa orang yang kemudian mengajak orang-orang yang memenuhi syarat untuk masuk dalam lingkup perkumpulan tersebut. Mereka menjadi satu kesatuan jaringan sosial. Terdapat aturan-aturan yang harus diikuti oleh semua anggota yang terkait dengan kewajiban masing-masing anggota, hak-hak yang diperolehnya, ketentuan kepengurusan perkumpulan, dan aturan pengecualian lainnya.

Berdasarkan hasil penelitian, tampak bahwa para pekerja perempuan memiliki jaringan sosial yang sebutannya berbeda-beda, namun pada dasarnya memiliki karakteristik sama. Perkumpulan-perkumpulan yang dapat dikategorikan sebagai modal sosial memiliki terminologi yang berbeda-beda. Di wilayah Sumatera Utara, perkumpulan orang-orang yang berasal dari satu wilayah yang sama disebut Perpulungen dengan menambah nama desa yang menjadi asalnya, misalnya perkumpulan orang-orang yang berasal dari desa Tanjung disebut Perpulungen Tanjung, perkumpulan yang berasal dari Berastagi disebut Persadaan Warga Berastagi dan Sekitarnya (PWBS). Ada pula perkumpulan berdasarkan marga, misalnya Perpulungen Ginting ras Anak Beruna, untuk marga Tarigan dinamai Perpulungen Tarigan ras Anak Beruna. Di daerah Jawa Timur disebut Paguyuban, dan seterusnya.

Pada masa pandemi COVID-19, pertemuan secara fisik memang tidak diadakan oleh para pengurus perkumpulan, namun informasi tetap berjalan sebagaimana biasanya, bahkan komunikasi antaranggota tidak pernah terhenti dan semakin aktif, terlebih dengan adanya perantaraan teknologi seperti WhatsApp Group. Masing-masing anggota berupaya berpartisipasi menyampaikan hal-hal penting terkait COVID-19, mulai dari tindakan preventif hingga kuratif. Selain itu, informasi tentang keadaan masing-masing keluarga, mulai dari keluarga yang sakit, isolasi mandiri, yang terdampak kebijakan terkait pandemi COVID-19 (dirumahkan, terkena PHK), serta berbagai informasi lainnya disampaikan dan disebarkan dalam perkumpulan dan jejaring yang telah dibuat. Tidak ketinggalan pula informasi pekerjaan yang tersedia baik yang bersifat tetap maupun sementara.

Tidak hanya itu, perkumpulan juga dapat menjadi tempat beredarnya informasi tentang ketersediaan barang dan jasa yang diperjualbelikan, layaknya marketplace. Di sinilah para pekerja perempuan dapat memulai usahanya yang baru. Bukan hanya diberi modal oleh pemberi bantuan, namun pihak-pihak yang membutuhkan bantuan ini (dalam hal ini para pekerja perempuan) juga diberi proyek tertentu, misalnya diberi rekomendasi tempat untuk membuka warung. Sirkulasi informasi ini kemudian menimbulkan efek domino berupa jejaring. Oleh karena itu, modal sosial yang berasal dari organisasi kedaerahan, memiliki kecenderungan untuk memfasilitasi tindakan bantu-membantu dengan cakupan sektor yang lebih luas karena para anggota yang memiliki latar belakang ekonomi dan profesi bermacammacam telah memiliki kesamaan nilai dan pandangan. Selain itu, anggota dari tipologi ini lebih banyak, dan memiliki sifat yang saling menguntungkan. Biasanya, anggota perkumpulan memprioritaskan untuk membeli barang dagangan anggota dalam WhatsApp Group mereka. Bahkan tidak jarang anggota grup berinisiatif untuk menawarkan ke grup lain untuk membantu penjualan temannya satu grup guna memperluas jejaring.

Dukungan dari anggota Perkumpulan tidak sekadar diwujudkan dalam kegiatan membeli dagangan. Anggota Perkumpulan tidak jarang memberi bantuan modal jika usaha sudah mulai berkembang dan membutuhkan suntikan dana. Biasanya tidak dikenakan bunga dan 
pembayarannya pun dalam dilakukan dengan cara mencicil. Kedekatan dan saling menjaga kepercayaan membuat kerja sama dalam Perkumpulan ini dapat berlangsung dengan lancar dan membantu bagi yang membutuhkan. Keberadaan Perkumpulan tidak hanya membantu perekonomian para pekerja perempuan, namun juga memberikan dukungan secara psikologis. Para anggota Perkumpulan saling berbagi pengalaman menghadapi berbagai permasalahan, seperti permasalahan terkait pembelajaran jarak jauh anak-anak mereka, serta menambah pemasukan rumah tangga dengan memanfaatkan sumber daya yang ada. Ada beberapa keluarga yang mengembangkan budikdamber (budidaya ikan lele dalam ember) dari hasil informasi teman dalam kelompok. Ternyata dengan tukar-menukar informasi di WhatsApp Group, mereka merasakan adanya pelepasan beban sehingga merasa lebih lega dan lepas dari kesulitan hidup yang menyesakkan.

\section{Simpulan}

Dari diskusi di atas dapat disimpulkan bahwa pandemi COVID-19 sangat berdampak bagi para pekerja perempuan di perusahaan. Terdapat pekerja yang mengalami PHK dengan pesangon, bahkan ada yang tanpa pesangon karena alasan berhentinya operasi perusahaan akibat pandemi. Ada juga pekerja yang dirumahkan tanpa upah dan dengan upah. Bekerja dari rumah dibayar penuh atau tidak dibayar penuh, juga dialami oleh beberapa pekerja perempuan. Selain itu, terdapat pula pekerja yang tetap bekerja dan hadir seperti biasa namun tidak dibayar penuh. Semua hal ini kemudian membawa dampak terhadap kehidupan sosial, ekonomi, dan psikologis mereka. Para perempuan yang biasa bergelut dalam pekerjaan di luar rumah, kini harus pula mengurus rumah tangga dengan keterbatasan perekonomiannya. Untuk itu, mereka harus melakukan manuver untuk mengatasi permasalahan yang dihadapi. Sebagai ibu rumah tangga, mereka harus menjaga ketersediaan kebutuhan untuk sarana pendidikan anak-anaknya yang sedang belajar dengan sistem Pembelajaran Jarak Jauh (PJJ), dan juga kebutuhan gizi bagi keluarga secara keseluruhan. Modal sosial yang dimiliki oleh para pekerja perempuan ternyata mampu membantu mereka dalam menghadapi dampak akibat kebijakan yang diberlakukan oleh perusahaan tempat mereka bekerja sehubungan dengan pandemi COVID-19. Jaringan-jaringan sosial yang terjalin dalam perkumpulan tersebut memampukan mereka bertahan bahkan ada beberapa yang menjadi lebih baik dari sebelumnya. Secara sosial, mereka juga merasa tidak terabaikan karena memiliki teman berkomunikasi walaupun hanya melalui media komunikasi daring. Tidak jarang pula para pekerja perempuan ini melakukan acara perkumpulan secara virtual.

\section{Referensi}

[1] Widyaningrum GL. WHO Tetapkan COVID-19 Sebagai Pandemi Global, Apa Maksudnya? National Geographic Indonesia, 12 Maret 2020, diakses dari https://nationalgeographic.grid.id/read/132059249/who-tetapkan-covid-19-sebagaipandemi-global-apa-maksudnya pada 26/8/2020

[2] Suara.com. AS Tertinggi, Indonesia Tempati Urutan 23 Dunia Sebaran Kasus Covid-19. dalam Cakaplah, 24 Agusutus 2020, diakses dari https://www.cakaplah.com/berita/baca/57976/2020/08/24/as-tertinggi-indonesia-tempatiurutan-23-dunia-sebaran-kasus-covid19\#sthash.rz4MTxoZ.dpbs pada 26/8/2020 
[3] Infeksi Emerging. Lima Protokol Penanganan Jadi Pedoman Utama Cegah dan Kendalikan COVID-19. Diakses dari https://covid19.kemkes.go.id/situasi-infeksiemerging/info-corona-virus/lima-protokol-penanganan-jadi-pedoman-utama-cegah-dankendalikan-covid-19/\#.X0jiGSgzbMw pada 28/8/2020

[4] Keeley B. Human Capital: How What You Know Shapes Your Life. (Paris: OECD Insights, 2007). 102

[5] Fathy R. Modal Sosial: Konsep, Inklusivitas, dan Pemberdayaan Masyarakat. Jurnal Pemikiran Sosiologi. 2019; 6(1): 1-6.

[6] Fine B. Theories of Social Capital: Research Behaving Badly. New York: Pluto Press, 2010. hlm. iii

[7] Fine B. What is Social Capital? Definition and Meaning. Market Business News 2020, diakses dari https://marketbusinessnews.com/financial-glossary/social-capital/ pada $29 / 10 / 2020$ 